\title{
PRACTICE AND PROCEDURE BEFORE THE ENERGY RESOURCES CONSERVATION BOARD
}

\author{
MICHAEL J. BRUNI* and KEITH F. MILLER**
}

\begin{abstract}
This paper discusses the jurisdiction and constitution of the Alberta Energy Resources Conservation Board and describes the basic functions discharged by the Board. It sets out the procedures followed at hearings and inquiries and provides a perception of the role of counsel in the process as representative of the applicant, intervener, or Board. The paper concludes with a brief discussion of local interveners' costs.
\end{abstract}

\section{INTRODUCTION}

It is becoming more and more apparent that the role of counsel before administrative tribunals is increasing both in frequency and in scope. Tribunals today are called upon to evaluate evidence set forth by many proponents representing conflicting interests. Boards initially created to discharge a purely technical mandate within both decision-rendering and regulatory regimes are now required to make broad public interest decisions. Proceedings before tribunals have therefore become increasingly adversarial in nature with a resultant increase in the attendance of counsel.

In Alberta, the Energy Resources Conservation Board (hereinafter referred to as the "Board") has been a party to this evolution. Where in the past decisions were made by the Board without major special interest objections, more decisions are now made after a lengthy hearing process with substantial participation by counsel. With more public involvement in the hearing process, there has been a tendency towards emphasis by the public and counsel on environmental, public interest, safety and impact matters, rather than on the more traditional conservation and technical matters handled by the Board in the past. This change in focus has had a substantial impact on the hearing and inquiry processes. Procedures which were once straightforward are now becoming complex. The discussion which follows outlines in general terms the jurisdiction and organization of the Board and the functions discharged by it. It then sets out the preliminary process leading up to a hearing or inquiry, followed by a detailed description of the basic procedures utilized by the Board. The role of counsel when representing the applicant, intervener or Board is outlined and the paper concludes with a discussion of local interveners' costs from both a practical and legislative perspective.

\section{THE LEGISLATIVE REGIME}

\section{A. General Jurisdiction and Organization of the Board}

The Energy Resources Conservation Board was established by The Energy Resources Conservation Act, ${ }^{1}$ under which it is charged with the regulation of the energy industry in the province, through the administration of the following Statutes and Regulations:

Oil and Gas Conservation Act ${ }^{2}$

* Manager of the Energy Resources Conservation Board's Legal Department.

* Solicitor in the Energy Resources Conservation Board's Legal Department.

1. R.S.A. 1980 , c. E-11, as am..

2. R.S.A. 1980 , c. 0-5, as am.. 


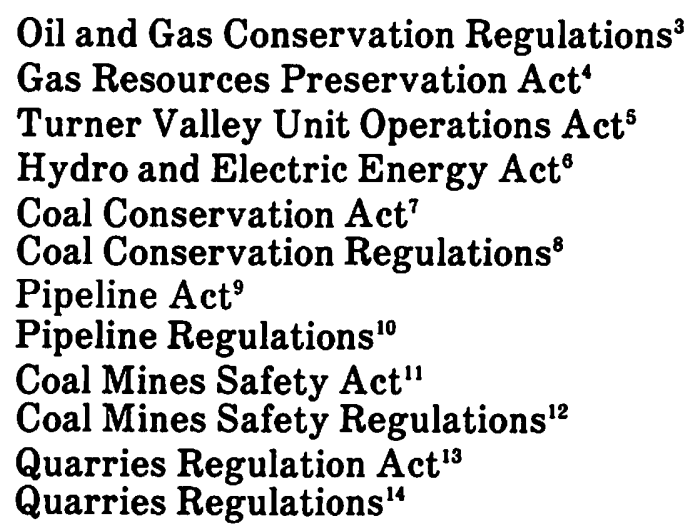

The responsibilities under the Coal Mines Safety Act and Regulations and the Quarries Regulation Act and Regulations are presently being discharged by the Occupational Health and Safety division of the Alberta Department of Workers' Health, Safety and Compensation.

The purposes of The Energy Resources Conservation Act $^{15}$ are set out in section 2 of that Act and are as follows:

2. The purposes of this Act are

(a) to provide for the appraisal of the reserves and productive capacity of energy resources and energy in Alberta,

(b) to provide for the appraisal of the requirements for energy resources and energy in Alberta and of markets outside Alberta for Alberta energy resources or energy,

(c) to effect the conservation of, and to prevent the waste of, the energy resources of Alberta,

(d) to control pollution and ensure environment conservation in the exploration for, processing, development and transportation of energy resources and energy.

(e) to secure the observance of safe and efficient practices in the exploration for, processing, development and transportation of the energy resources of Alberta,

(f) to provide for the recording and timely and useful dissemination of information regarding the energy resources of Alberta, and

3. Alta. Reg. $151 / 71$, as am.. The Board may make regulations under the 0 il and Gas Conservation Act, supra n. 2, pursuant to s. 10(1).

4. R.S.A. 1980, c. G-3, as am.. The Lieutenant Governor in Council may make regulations under the Gas Resources Preservation Act pursuant to s. 15. Alta. Reg. 447/78 is the only regulation under the Act.

5. R.S.A. 1980, c. T-12, as am.. The only regulations under the Act designate Units 1 to 7, as am..

6. R.S.A. 1980, c. H-13,as am.. The Board may make regulations under the Act, pursuant to s. 3(1) and 3(3) and with the approval of the Minister of the Environment, pursuant to $\mathrm{S}$. 3(4). No regulations are presently in force under the Act.

7. R.S.A. 1980 , c. C-14, as am..

8. Alta. Reg. 229/74, as am.. The Lieutenant Governor in Council may make regulations under the Coal Conservation Act, supra n. 7, pursuant to s. 9(1).

9. R.S.A. 1980, c. P.8, as am..

10. Alta. Reg. 298/75, as am.. Alta. Reg. $295 / 75$ sets out the forms and fees under the Pipeline Act, supra n. 9. The Lieutenant Governor in Council may make regulations under the Act, supra n. 9, pursuant to s. 3(1). The Board may prescribe forms and fees pursuant to $\mathrm{s}$. 4.

11. R.S.A. 1980, c. C-15, as am..

12. Alta. Reg. 333/75, as am.. The Lieutenant Governor in Council may make regulations under the Coal Mines Safety Act, supra n. 11, pursuant to s. 7(1).

13. R.S.A. 1980, c. Q-1, as am..

14. Alta. Reg. 38/57, as am. and Alta. Reg. 371/70, as am.. The Lieutenant Governor in Council may make regulations under the Quarries Regulation Act, supra n. 13, pursuant to s. 3.

15. Supra n. 1. 
(g) to provide agencies from which the Lieutenant Governor in Council may receive information, advice and recommendations regarding energy resources and energy.

Notwithstanding the absence of individual provisions, the Board has considerable powers to effect these purposes which are consistent with those set out in the other statutes it administers. ${ }^{16}$

Under section 3 of the Energy Conservation Act ${ }^{17}$ the Energy Resources Conservation Board is continued as a corporation. The Act specifies that the number of Board Members shall not exceed seven and appointments shall be made by the Lieutenant Governor in Council. ${ }^{18} \mathrm{As}$ of January 1, 1982, the Board consisted of Mr. V. Millard, Chairman, Dr. N. Berkowitz, Vice Chairman, Mr. G. J. DeSorcy, Vice Chairman, and Board Members Mr. V. E. Bohme, Mr. C. J. Goodman and Mr. N. Strom. The Lieutenant Governor in Council may nominate persons from which the Board may select Acting Board Members, providing there are not more than nine Board Members during any period of time. ${ }^{19}$ There are presently outstanding Orders In Council from which the Board can call upon senior Board staff within the organization, senior members of the Department of the Environment, senior members of the Department of Agriculture and members of the Public Utilities Board as Acting Board Members. Such selection is dependent upon the nature of the proceeding and usually will require Acting Board Members to conduct a Board hearing or inquiry.

The Board will seldom sit as a full Board at a hearing or inquiry. The Chairman will usually designate three members to constitute a division of the Board which will decide the matter before it. ${ }^{20} \mathrm{It}$ is not necessary that the division report back to the Board as the decision of the division is binding on the whole Board. ${ }^{21}$

The Board may also appoint examiners from its staff for the purpose of conducting hearings and discharging other duties..$^{22}$ Again, a panel will usually consist of three examiners who are appointed to conduct the hearing or inquiry, the examiners will issue an examiners' report recom-

16. Oil and Gas Conservation Act, supra n. 2, s. 4,

Gas Resources Preservation Act, supra n. 4, s. 3 ,

Hydro and Electric Energy Act, supra n. 6, s. 2,

Coal Conservation Act, supra n. 7, s. 4,

Pipelines Act, 1975, supra n. 9, s. 5 ,

Coal Mines Safety Act, supra n. 11, s. 3.

Section 21 of the Energy Resources Conservation Act, supra n. 1, grants the power to the Board to effect the purposes of the Act. An equivalent provision is found in the following Statutes:

Oil and Gas Conservation Act, supra n. 2, s. 7 and 86 ,

Hydro and Electric Energy Act, supra n. 6, s. 5,

Coal Conservation Act, supra n. 7, s. 7.

Under s. 7(4) of the Energy Resources Conservation Act, supra n. 1, a division of the Board may exercise and perform all the jurisdiction, powers and duties of the Board under this Act or any other Act with respect to the hearing, inquiry or investigation it is directed to conduct. Section 15 of the Energy Resources Conservation Act, supra n. 1 . grants incidental powers to the Board.

17. Supra n. 1.

18. Id., s. 4 .

19. Id. s. 6.

20. Id., s. 7(1), supra n. 16, s. 7(4) grants the division all powers of the Board.

21. Id., s. 7(3).

22. Id. s. 16(d) and 17 . 
mending a disposition of the matter and the Board will make the final disposition. A copy of the examiners' report must be forwarded to each registered participant by the Board. ${ }^{23}$

A participant may apply to have the proceeding conducted by the Board at which time the examiners have no alternative but to put the request before the Board, who must determine whether to hear the matter or have it continued às an examiners' hearing or inquiry. ${ }^{24}$

Although hearings and inquiries have increased substantially, they still only assist in discharging a small portion of the responsibilities imposed upon the Board as an organization. As of December 31, 1980, the Board employed a staff of approximately 649 , of which 80 percent are located in the Calgary Head Office, with the remainder in the Core Research Centre in Calgary, the Chemical Laboratory in Edmonton and in seven area offices located at various locations in Alberta. The majority of applications and matters handled by the organization never proceed to a hearing or an inquiry and accordingly, seldom involve or require counsel.

A later section of this paper will discuss those matters which usually proceed to a hearing or inquiry.

\section{B. The Nature of Board Functions}

To fully appreciate Board procedure and the role of counsel at hearings and inquiries, it is necessary to understand the basic functions being discharged by the Board in these proceedings and particularly how the public process fits into this functional framework. As a creature of statute, the Board is restricted to administering its statutory jurisdiction and, in doing so, it discharges two basic functions. It performs an approving or adjudicative function as required by individual statutory provisions which may include a Board public hearing. ${ }^{25}$

It must also perform an advisory or investigative function when called upon to do so by the Lieutenant Governor in Council, or it may perform

23. Id. s. 17.

24. Id. s. 36 and Rules of Practice, s. 29.

25. Under its approving or adjudicative function, the Board discharges an important regulatory function by carrying out duties assigned by both its Statutes and Regulations. 
such a function on its own initiative. ${ }^{26}$ This latter function may result in a Board inquiry, if the Board considers an inquiry necessary and appropriate. ${ }^{27}$

It is possible for the Board to discharge the obligations imposed by both these functions by holding a joint hearing-inquiry. This has occurred on several occasions at which the Board rendered, in one document, a decision as a result of the hearing portion and rendered observations and recommendations as a result of the inquiry portion. ${ }^{28}$

A question which does arise is whether the Board must expressly initiate its investigative function, or whether it can rely on it being an implied part of any public hearing process. This question obviously does not arise if the functions are being discharged by separate proceedings or if they are being discharged by way of a joint proceeding specifically held for that purpose. ${ }^{29}$ If the Board does not expressly initiate its investigative function, that is, by way of Notice or otherwise, and is not requested to do so by the Lieutenant Governor in Council, then the delineation of its functions and the consequences of this delineation become very important. This matter was in part at issue before the Alberta Court of Appeal in the Alsands case. ${ }^{30}$ The decision rendered by the Court of Ap-

26. Pursuant to Order in Council O.C. 332/81, the Board has been ordered to inquire into and report on alternative locations for a suitable point of interconnection with facilities of the British Columbia Hydro and Power-Authority. This has been registered as Board Proceeding 810326. See Notice, Appendix C.

Supra n. 1, s. 22, reads as follows:

24. (1) The Board may, and at the request of the Lieutenant Governor in Council shall, at such places, at such times and in such manner as it considers advisable

(a) make inquiries and investigations and prepare studies and reports on any matter within the purview of any Act administered by it relating to energy resources and energy, and

(b) recommend to the Lieutenant Governor in Council such measures as it considers necessary or advisable in the public interest related to the exploration for, production, development, conservation, control, transportation. transmission, use and marketing of energy resources and energy.

Also refer to $\mathbf{s .} 9$ of the same Act.

Other Statutes administered by the Board have their own specific provision:

Oil and Gas Conservation Act, supra n. 2, s. 86,

Hydro and Electric Energy Act, supra n. 6, s. 4.

Coal Conservation Act, supra n. 7, s. 8,

Pipeline Act, supra n. 9, s. 5 and 29.

27. Id. In the Notice of Inquiry for Board Proceeding 810326, the Board requested submis. sions by a certain date and included the following paragraph:

AND FURTHER TAKE NOTICE that providing the submissions filed demonstrate a need for further consideration, the Energy Resources Conservation Board will hold a public inquiry at 9:00 a.m., on Tuesday, 27 October 1981, at the Elks Community Hall No. 15, 20 Avenue and 29 Street, Blairmore.

See Appendix C, which is a copy of the entire Notice of Inquiry for Board Proceeding 810326.

28. ERCB Decision 79-E, October 1979, entitled "Esso Resources Canada Limited under Section 43 of The Oil and Gas Conservation Act and Section 27 of The Coal Conservation Act for an In-Situ Recovery Project and Upgrading of Crude Bitumen to Produce Synthetic Crude Oil and the Use of Coal as Fuel for the Scheme".

29. Id. at 5. The Board expressly initiated its investigatory function pursuant to s. 22 of Energy Resources Conservation Act, supra n. 1.

30. Athabasca Tribal Council v. Amoco Canada Petroleum Company Ltd. et al (Alsands) (1980) 22 A.R. 541 (Alta. C.A.). 
peal was appealed to and argued before the Supreme Court of Canada. ${ }^{31}$ The issue of importance to the Board's jurisdiction was whether the Board could place a condition upon its approval of the applicant's proposed project by requiring that the applicant (Alsands) enter into an affirmative action program. Framed generally in terms of the Board's jurisdiction, the issue concerned the Board's treatment of public interest and more particularly, social impact concerns, in arriving at a decision.

The Board's perception of dealing with these impacts as part of its decision-making function is clear. As part of its approving function, the Board considers not only requirements imposed by the individual statutory provision requiring approval, but also environmental, social impact and public interest concerns in evaluating the application before it. ${ }^{32}$ The Board has taken the position that it does have authority to consider these latter matters in the general sense, to determine only whether the impacts are of such a magnitude to preclude the project in question from proceeding. However, in the writers' opinion, the Board cannot, as part of its approving function, take the next step of remedying these impacts by way of a condition to its approval. Pursuant to the Board's advisory or investigative function, it may advise the government of these impacts, if such do not result in the denial of the application, so that the government agency with the appropriate jurisdiction may remedy the impacts. ${ }^{33} \mathrm{Fur}$ ther, if an Order in Council is required, an applicable condition may be appended to the Order in Council at the discretion of the Lieutenant Governor in Council to remedy the impact. ${ }^{34}$

In the Alsands decision, Mr. Justice Laycraft agreed in part with the Board's position, so far as it related to pre-existing impacts, but the decision is unclear as to impacts created by the project itself..$^{35}$

In discharging its approval function, the Board must act judicially, and accordingly it is subject to procedural rules of fairness. The public hearing process in itself assists the Board in complying with these rules. As an advisory body the Board is also subject to rules of fairness, but only insofar as its dispositions may affect third parties. The common law rules of fairness have been codified in section 29 of the Energy Resources Conservation Act. ${ }^{36}$ The Board is subject to the Administrative Procedures $\mathrm{Act}^{37}$ and is afforded the powers of a commissioner under the Public Inquiries Act. ${ }^{38}$ When discharging its approving function at a hearing or its

31. Argument took place before the Supreme Court of Canada on December 4 and 5, 1980. The Supreme Court dismissed the appeal on June 22, 1981. All nine justices concurred in the result, although two separate opinions were written.

32. The Board takes this position in light of the purposes of the statutes which it administers, supra $\mathrm{n} .15$ and 16 . There is also reference to public interest in several specific provisions in the statutes administered by the Board. For example, s. 30(6) of the Oil and Gas Conservation Act, supra n. 2, s. 16 of the Hydro and Electric Energy Act, supra n.6, and s. 34 of the Pipeline Act, supra n. 9.

33. Supra n. 1, s. 22(b). In part this involves a discharge of the function perceived by s. 22(b).

34. Supra n. 2, s. 8, envisages this situation. Similar provisions are found throughout the Statutes administered by the Board which particularly require approval of the Lieutenant Governor in Council.

35. Supra n. $\mathbf{3 0}$ at $\mathbf{5 5 5}$ and $\mathbf{5 5 6 .}$

36. Supra n. 1.

37. R.S.A. 1980, c. A-2, as am.. This Act applies to the Energy Resources Conservation Board by virtue of Alta. Reg. 135/80.

38. R.S.A. 1980, c. P.29, as am.. This Act applies to the Energy Resources Conservation Board by virtue of s. 39 of the Energy Resources Conservation Act, supra n. 1 . 
advisory function at an inquiry, the Board is not bound by the rules of law concerning evidence. ${ }^{39}$ The Board does have Rules of Practice (hereinafter sometimes referred to as the "Rules") which it follows but, as will become apparent in the later procedural discussion, the Board will deviate from these when fairness requires ${ }^{10}$ The lack of evidentiary rules and the ability to deviate from its Rules of Practice, allow the Board the flexibility to more easily maintain fairness within the hearing and inquiry processes. If one alleges unfair treatment, there are applicable appeal provisions. ${ }^{41}$

From the foregoing, it becomes clear that the Board is restricted jurisdictionally when discharging its approving function. It must pay attention to individual statutory provisions creating the obligation and to rules of fariness. On the other hand, the Board has a greater jurisdictional flexibility in discharging its advisory function, especially when doing so separately from its approving function, in that it is not rendering a decision but only making observations and rendering recommendations. As will become apparent, the Board procedures which have evolved as a result of these functions have been tailored by these jurisdictional limitations.

\section{PROCEDURE OF THE BOARD}

\section{A. Proceeding to a Hearing or Inquiry}

Under the statutes administered by the Board, approval is required prior to proceeding with many energy-related projects. ${ }^{42}$ Application must be made to the Board requesting approval. There is also provision for the Board to unilaterally initiate its approving function..$^{43}$ The Rules of Practice of the Energy Resources Conservation Board set out the procedure to be followed when filing applications and the form that the application should take. ${ }^{44}$ Certain applications must be made pursuant to standard application forms. ${ }^{45}$ The content of the application and supporting material will vary with the nature of the approval sought as well

39. Supra n. 1, s. 30(2). Section 40(1) requires giving of evidence notwithstanding that it might incriminate the witness. Section 40(2) affords the protection of $\mathrm{s} .5$ of The Canada Evidence Act, R.S.C. 1970, c. E-10, as am., and s. 6 of the Alberta Evidence Act. R.S.A. 1980 , c. A.21, as am..

40. Alta. Reg. 149/71, as am.. Section $4(1)$ affords the Board this flexibility. as well as ss. 18 . 19,29 and 30.

41. Supra n. 1, s. 43 affords a remedy to a person not receiving notice. Section 44 sets out ap. peal provisions on a question of law or of jurisdiction. Section 42 allows the Board to reconsider or review any of its decisions. The Board is reluctant to do so unless changed circumstances are demonstrated by the applicant. Section 45 is a privative clause. Sec. tion 28 deems any actions of the Board as final and conclusive.

42. Refer to Schedule in Appendix E.

43. Id., s. 29(1).

44. Supra n. 40, ss. 5, 6, 7 and 8.

45. Two such applications are those for pipeline permits and licences, which must be by way of form PL100, pursuant to Alta. Reg. 44/77, as am. and well licences. Transfer of a pipeline permit and licence must be by way of form PL110, set out as Schedule 1, Alta. Reg. 47/77, as am.. Transfer of a well licence must be by way of the form set out in Schedule 1, Alta. Reg. 151/71. 
as the statutory provision requiring the approval and any relevant regulation. ${ }^{46}$

The content could also be influenced by pertinent informational letters and interim directives issued periodically by the Board..$^{47}$

If a valid objection to an application is received by the Board, either in response to a Notice for objections or otherwise, the matter will usually be set down for a Board or Examiners' hearing. ${ }^{48}$ The Board may also call a hearing if the subject matter of the application is of major public interest notwithstanding the absence of objections. ${ }^{49}$

If a hearing is to be held, a Notice of Hearing is prepared in accordance with the Rules and distributed as the Board deems appropriate. ${ }^{50}$ The notice will set out the particulars of the hearing, the date before or upon which submissions should be filed in accordance with the Rules and advise if the hearing is to be conducted by examiners. ${ }^{51}$ It may further indicate that certain matters which may be of concern to prospective interveners are outside the scope of the Board's jurisdiction and accordingly will not be considered at the hearing. ${ }^{52}$ In exceptional situations when the Board staff is to make a submission, this will also be reflected in the Notice along with details of its availability for perusal by prospective participants..$^{53}$

As outlined earlier, the Lieutenant Governor in Council may request the Board to inquire into and investigate certain energy-related matters and/or events and report back with its observations and recommenda-

46. Supra n. 3, Part 15. Although there are several provisions in these regulations and regulations made pursuant to other statutes administered by the Board. Part 15 demonstrates examples of such provisions as they relate to specific applications. See Schedule in Appendix $\mathbf{E}$.

Supra n. 2, s. 10(4). This affords the Board flexibility in deviating from application requirements as set out in the regulations. A similar provision is found in other statutes administered by the Board:

Hydro and Electric Energy Act, supra n. 6, s. 3(2),

Coal Conservation Act, supra n. 7, s. 9(3),

Pipeline Act, supra n. 7, s. 3(2).

47. For example, ERCB Interim Directive ID.OG 77-1 with respect to industrial development permit applications under s. 30 of the Oil and Gas Conservation Act, supra n. 2 and Information Letter IL 79-13, with respect to common purchaser orders and s. 39 of the same Act. The latter informational letter deals with the administration respecting com. mon gas purchaser applications and orders.

48. A Notice for objections will be prepared in accordance with the Rules of Practice, supra n. 40, s. 9 and the Energy Resources Conservation Act, supra n. 1, s. 37. Section 17 of the Rules of Practice allows the Board not to have a hearing if the objection is of little merit. Further, the Board tends to favour having a hearing as opposed to receiving written submissions pursuant to s. 29(3), when a valid objection has been filed. This section is similar to s. 6 of the Administrative Procedures Act, supra n. 37. See Appendix A for example of Notice for objections.

49. Examples of such applications are oil sands projects under s. 31 of the Oil and Gas Conservation Act, supra $\mathrm{n} .2$ and applications under Part 10 of that same Act for common carrier. purchaser and processor declarations. An application is complete when all deficiency letters sent out by Board staff have been responded to.

50. Supra n. 40, s. 10 and supra n. 1, s. 37. Distribution is within the Board's discretion. See Appendix B for examples of Notice of Hearing.

51. The Notice of Hearing will indicate that copies of the application may be obtained from the applicant or a designated agent. Section 11 of the Rules requires an applicant to supply applications to interested persons upon request.

52. A statement is commonly included indicating that compensation is outside the Board's jurisdiction. See Appendix B(b).

53. Supra n. 40, s. 27. 
tions. ${ }^{54}$ The Board may also initiate this investigative function unilaterally as a separate proceeding or jointly when discharging its approving function..$^{55}$ The issues arising as a result of an implied initiation of the investigatory or advisory function as part of the hearing of an application have already been discussed.$^{56}$ However, one question which remains unanswered in that regard is whether an inquiry can be held when the Notice only specifies a hearing of a particular application and not an inquiry into certain matters.

The subject matter being investigated by the Board will usually fall into one of two categories. Firstly, it may be an event requiring further investigation and recommendations to prevent its future occurrence. ${ }^{57}$ Secondly, it may be an area in which the Board requires public response and submissions so as to formulate basic data that it will utilize in its future operations or advice to the government. ${ }^{\$ \$}$

Whatever the subject matter, in discharging this investigative function the Board is not required, unless specifically requested to do so by the Lieutenant Governor in Council, to have an inquiry. If, as part of the process, the Board deems it appropriate and necessary, it will call either a Board or Examiners' inquiry ${ }^{59}$ Having made this decision, a Notice of Inquiry will be prepared with its distribution varying greatly depending on the nature of the inquiry. ${ }^{60}$ If the inquiry is to be open to the public the Notice may invite written submissions by a particular date. If the attendance at the inquiry is to be restricted to particular participants then the Notice will reflect this but may also request written submissions from those required to attend. The Notice will outline in detail the subject matter of the inquiry and reasons for the holding of the inquiry as well as advise whether the inquiry is to be conducted by examiners. Quite often the inquiry will be preceded by substantial preliminary work by Board staff which may result in their making a submission to the inquiry. ${ }^{61}$ If a written Board staff submission is being prepared, its availability for perusal will be set out in the Notice. Notices to Attend, demanding attendance at the inquiry, may be sent out by the Board where the attendance and evidence of certain participants is deemed necessary to assist the Board in formulating both its observations and recommendations. ${ }^{62}$

If a joint hearing-inquiry is to take place a combined Notice of Hearing and Inquiry will be issued clearly reflecting the dual nature and purpose of the proceeding.

54. Supra n. 26.

55. Supra n. 26, 28 and 29.

56. Supra $\mathrm{n} .30$ and 31 .

57. An example is Board Proceeding 790161, "Pipeline Failure Inquiry". Mill Woods Area, Edmonton, held in May, 1979. Often these events will result in a contravention of a statute administered by the Board.

58. An example is Board Proceeding 800119. "Energy Resource Requirements. 1981-2005”. held in April 1981, hy the Board. Supra n. 27 and see Appendix C.

59. Supra n. 27.

60. Supra n. 40, s. 10 and supra n. 1, s. 37, distribution again is within the Board's discretion. See Appendix C for example of Notice of Inquiry.

61. Supra n. 53.

62. See Appendix D. Included in Appendix D is an example of a Notice to Attend and Produce and a Notice to Appear. The former is served upon a company demanding attendance of an officer and necessary documentation. A Notice to Appear is served upon individuals. 
The Board is required to give a minimum period of ten days notice of a hearing and adopts this same minimum time frame for Notices of Inquiry ${ }^{63}$ Notwithstanding, the Board normally issues the Notice of the proceeding five to eight weeks prior to its commencement. Written submissions are required to be received by the Board approximately one week before the hearing date ${ }^{64}$ This latter time will vary considerably for individual inquiries.

\section{B. Hearing Procedure}

After expiration of the time between the issuance of the Notice of Hearing and the date of the hearing, the next step in the process is the hearing itself. The Board endeavours to strike a balance between flexibility and formality to maintain fairness, orderliness and expediency in considering an application at a hearing. ${ }^{65}$ Although the Rules of Practice form the basis for the hearing procedure, the Board will deviate from them in appropriate circumstances. ${ }^{66}$

The participants at any hearing, whether conducted by examiners or the Board, fall into two categories: the applicant and interveners. Interveners may make submissions in support of or in opposition to the application and file a written submission in accordance with the Rules by the date set out in the Notice of Hearing. ${ }^{67}$ Those making an intervention must have a bona fide interest in the matter or the Board may refuse to hear the intervention. ${ }^{68}$ There is provision in the Rules for government department submissions. ${ }^{69}$ Government departments are not subjected to cross-examination under that provision and very seldom give direct evidence other than in written form, pursuant to section 26 of the Rules.

When the Board staff desires to take a position on a matter before the Board it may and should make a submission as provided in the Rules. ${ }^{70} \mathrm{~A}$ written submission will be filed and made available for perusal prior to the hearing. In Board initiated proceedings the submission will give background facts leading up to the hearing. ${ }^{71}$ At the hearing, the staff present the submission with assistance from Board counsel and they are later subject to questioning from all parties but are not given the opportunity of presenting final argument.

The hearing is commenced with opening remarks by the chairman of the panel describing the matter to be considered, sitting hours and other logistic matters. He will then call upon the participants and their representatives to be registered, being only those who have sent in writ-

63. Supra n. 1, s. 37(2).

64. Supra n. 40, s. 12 and 13.

65. When hearing and inquiry procedures are discussed in this study and reference is made to the Board such provisions are equally applicable to examiners. The Energy Resources Conservation Act, supra n. 1, s. 32, is applicable to all hearings and inquiries held pursuant to any Act administered by the Board.

66. Supra n. 40.

67. Supra n. 40, ss. 12, 13, 14, 15, 16 and 23. Section 15 of the Rules allows the Board to require an intervener to supply copies of his intervention to specified parties. Usually he will supply same voluntarily.

68. Id. ss. 19 and 21 .

69. Id, s. 26.

70. Supra n. 53.

71. Such a Board Staff Submission was made to Board Proceeding 810078 with respect to province-wide spacing at a Board hearing in Edmonton, March, 1981. 
ten submissions in response to the Notice of Hearing. Prospective interveners who do not file written submissions must request leave from the Board to appear. ${ }^{72}$ This occurs after registration has taken place and the Board will request the comments of other participants before making a ruling. Upon resolution of the list of participants, the details of distribution of the Notice of Hearing will be provided by either Board counsel or Board staff. Order of registration is a matter within the discretion of the Board and often is formulated so as to have similar interventions presented consecutively. This tends to avoid repetition of similar evidence by related interventions. The chairman will subsequently file all submissions made by government departments pursuant to section 26 of the Rules, as exhibits. The Notice is not entered as an exhibit to the proceedings.

A transcript is maintained at all hearings. The Board does not require and will not compel evidence to be given under oath.

Any preliminary motions for adjournment are made at the outset of the hearing immediately prior to the applicant making his submission. The Board will usually retire and return with its decision and reasons. In exceptional circumstances, the Board has entertained motions for adjournment prior to the hearing. ${ }^{73}$ This occurs when all prospective participants can be advised and a preliminary meeting can take place. ${ }^{74}$ Having dealt with all preliminary matters, the Board will then call upon the applicant to present its application and witnesses. Documents are entered as exhibits at the outset of individual presentations. ${ }^{75} \mathrm{It}$ is becoming common to enter expert and policy evidence through panels and later subjecting the whole panel rather than individual witnesses to cross-examination.

The applicant's witnesses may then be cross-examined by the interveners in order of registration..$^{76}$ Next, Board counsel will ask questions with the assistance of the Board's technical and economics staff. The questions usually attempt to complete the application by obtaining additional data to assist the Board in its decision-making process. Members of the Board will then be given the opportunity to question the witnesses. The applicant may present redirect evidence if necessary.

Upon completion of the applicant's evidence, the interveners present their evidence and are subject to cross-examination by other participants. ${ }^{77}$ Whether the applicant cross-examines before or after all the interveners have had the opportunity to question is within the panel's discretion. The Rules provide for participation in a hearing for the purpose of cross-examination and argument only.$^{78}$ Often interveners utilize this provision and accordingly will not present direct evidence nor be subject to cross-examination.

After all interveners' evidence has been presented, the applicant will be allowed to rebut any evidence given by interveners during their direct

72. Supra n. 40, s. 16 and 23.

73. An example of this occurred with the adjournment of application 800910 by NOV A/Shell for an industrial development permit.

74. Supra n. 40, s. 20.

75. Id. ss. 22 and $24(1)$.

76. Id. ss. $25(1)$ and $25(2)$.

77. Id. ss. 22 and $24(1)$.

78. Id., ss. $14(1)(\mathrm{e})$ and $22(1)$. 
testimony or as a result of cross-examination. The panel is reluctant to allow cross-examination of rebuttal evidence unless the evidence is entirely new to the proceedings.

Often counsel for the applicant will object to direct evidence not clearly set out in the written submissions tendered in response to the Notice of Hearing. ${ }^{79}$ Many written interventions give no indication of the position to be taken by the participant, who may later take an adverse position when giving evidence at the hearing. Again, the Board, prior to determining whether this evidence should be heard, will listen to the arguments and will base its ruling on fairness and the importance of the evidence in arriving at a final decision.

Participants will occasionally request the panel to recognize evidence presented at an earlier Board or Examiners hearing. If all participants consent and the actual transcript excerpt is tendered as an exhibit, the panel is more likely to admit the evidence.

The Board has powers under the Energy Resources Conservation Act to compel the production of evidence. ${ }^{80}$ The Board seldom utilizes these powers. However, it has been requested to compel a response when a witness refused to respond to a question posed on cross-examination and to compel the attendance of witnesses. The evidence in each case may be of a proprietary nature requested by a competitor. If the Board considers the evidence to be important, it will request it and advise the witness that the lack of a reasonable response may influence the final determination of the matter or the weight given the intervention, as the case may be. ${ }^{k 1}$

When witnesses are unable to supply an appropriate response to questions posed on cross-examination, they may undertake to supply it later in the proceedings. This response will usually be supplied through redirect examination, or rebuttal evidence if made through the applicant's witnesses. The Board will allow follow-up questioning, resulting from the evidence supplied by way of the undertaking. It is for this reason that the Board is reluctant to receive evidence after the close of the hearing, as resulting questions may require a reopening of the hearing. ${ }^{82}$ If the undertaking requires further written submissions, they must be supplied to all participants. Notwithstanding the Board's reluctance to receive evidence after the close of the hearing, if the evidence is of a very technical nature and clearly non-contentious, the Board will allow it to be submitted after the close of the hearing, again requiring it to be sent to all participants.

The Rules require interventions to be presented by at least one witness. ${ }^{83}$ Written interventions received by the Board and not presented by witnesses are given little weight in the whole decision-making process. They are not entered as exhibits and may or may not be referred to in the decision report.

Notwithstanding its exemption from the technical rules of evidence, the Board does require that evidence presented be relevant to the issues

79. ICL, s. 24(1).

80. Supra n. 1, ss. 39 and 41.

81. Supra n. 40, s. 28. The Board will not accept evidence on a proprietary hasis.

82. The question of utilization of evidence received after the close of the hearing was in part at issue in Rozander and Groeneveld v. E.R.C.B. and Calgary Power Ltd. $(\$ 1)(1978) 13$ A.R. 461 and Rozander and Groeneveld v.E.R.C.B. and Calgary Power L td. $1 \pm 21(1978) 13$ A.R. 479 .

83. Supra n. 40, s. 22(1). 
before it. ${ }^{84}$ Although it takes a flexible approach to relevancy, it will periodically remind counsel and witnesses of their responsibilities to stay on point. This is difficult to control at times when participants envisage the Board hearings as the only forum to present their views and feelings on the project in question. Counsel, especially for industry, tend to become frustrated with seemingly irrelevant evidence unnecessarily prolonging the proceedings. As indicated earlier, the Board takes the position it must have regard to the general public interest and consider evidence dealing with public interest in determining the issues before it.

The final segment of the hearing allows participants to make a closing statement or argument. ${ }^{85}$ Interveners are given their opportunity in order of registration and the applicant argues last. Argument usually reflects upon the evidence presented during the proceedings, clarifying the particular participant's position and desired disposition of the matter. Interveners are not normally given an opportunity to reply to the applicant's argument. Upon completion of argument, the Board will reserve its decision and close the hearing. Examiners will also reserve their recommendations prior to the close of the hearing and will present them to the Board at a later date. The Board issues decision reports for all matters which go to Board hearings. Examiners' reports are prepared but do not necessarily result in a Board decision report. Board decision reports and Examiners' reports are distributed to all participants. ${ }^{\text {"6 }}$

In exceptional circumstances, the Board may issue an interim decision a few days after the hearing with a more detailed decision report to follow. ${ }^{87}$ The Board will do this if timing is critical to the applicant and approval is not really in question. In normal situations, the Board will issue a decision two to three months after the close of the hearing. ${ }^{88}$

All decisions of the Board, whether made in discharging its approving function by way of a hearing or made internally without a hearing, must be implemented. The Board implements its decision by issuing approvals, orders, licences and permits. Depending on the particular statutory provision requiring approval, the Board may issue these instruments without further ratification or may require Ministerial approval. ${ }^{89} \mathrm{Cer}$ tain decisions cannot be implemented until an Order in Council is issued by the Lieutenant Governor in Council. ${ }^{90}$

84. Supra n. 39.

85. Supra n. 40, s. 24(2). Occasionally the Board may allow written argument. It tends to avoid this since time must be given between the intervener's and applicant's argument thus prolonging the decision.making process.

86. Supra n. 1, s. 17, with respect to examiners' reports and as required by $s .7$ of the Administrative Procedures Act, supra n. 37.

87. An example is Application 800319, by Gulf Canada Resources Inc. for a gas processing plant in the Robb-Hanlan Area, resulting in Decision Report 81-1. The Board hearing was completed on November 13,1980, and an interim decision issued November 21, 1980 . Decision Report 81-1 was issued January 22, 1981.

88. This timing may be somewhat conservative if Ministerial approvals and/or Orders in Council are required.

89. It may be necessary to refer an application to the Minister of Environment and/or the Minister of Energy and Natural Resources for their approval of the application if it affects matters of the environment. Terms and conditions may be appended to the approval.

90. Supra n. 33 and 34. The Lieutenant Governor in Council may impose terms and conditions to the Order in Council affirming the Board's decision if appropriate. 
When circumstances warrant, the Board may call upon pre-hearing and post-hearing conferences to assist in the hearing process. ${ }^{91}$ Although prehearing conferences have not been utilized extensively by the Board to date, there may be a need for these in the future to assist in defining variations in procedures to be followed for the particular hearing. As referred to earlier, in the past the Board has dealt mainly with motions for adjournment in the pre-hearing conferences it has called. ${ }^{92}$ These pre-hearing conferences are held before a division or quorum of the Board which will not necessarily include those members designated to conduct the hearing. This latter factor is of no consequence since the merits of the application or intervention are neither presented nor considered in determining the preliminary matter. Notice of a pre-hearing conference is given to all known participants. A transcript is usually not maintained.

The format of post-hearing conferences is somewhat different. When a portion of an application is very technical in nature and the Board staff have technical questions, the Board may request such questioning to take place at a post-hearing conference. Providing there are no objections, all participants will be advised and invited to attend. The Board is usually not present. The applicant's witnesses are usually questioned by a senior member of the Board staff. Other participants will not usually question on these very technical matters and a transcript is not maintained.

From the foregoing discussion one can appreciate the flexibility built into the hearing process. In spite of this, the Board is particularly cognizant of the rules of fairness and will attempt to discharge its fairness obligations at the expense of expediency. Counsel generally frown upon this flexibility and prefer to represent their clients' interest within a more formal procedure. With more counsel becoming involved in the hearing process formalization may be a necessity. Some parties fear that formalization will burden the decision-making process with useless legalistic procedure. The answer is probably a compromise between total flexibility and total formality.

\section{Inquiry Procedure}

The procedure at an inquiry, whether conducted by the Board or examiners, is clearly different from that followed at a public hearing. This can be attributed in part to inherent differences in the functions being discharged by the Board.$^{93}$ Because of the investigative and informationgathering nature of the inquiry process, the Board not only may, but often must, utilize procedural flexibility.

The nature of the inquiry will be influenced by the subject matter being investigated as well as the evidence which will assist the Board in discharging its function. The basic difference between inquiries themselves is characterized by the participants to that inquiry. As noted earlier, the Board may allow only those served with the Notice to Attend the right to file a submission and to participate later in the inquiry. On the other hand, the inquiry may be completsly open to the public, inviting both the public's written submissions and participation. In any event, many inquiries, although open to the public, will only be of interest and applicability to a small group of participants.

91. Supra n. 40, ss. 18,19 and 20.

92. Supra n. 72.

93. Supra n. 26. 
Although the Board will serve Notices to Attend on desired participants, it prefers not to require attendance by way of an order of the Court of Queen's Bench if Notices to Attend are not complied with. ${ }^{94}$

The Board follows a basic procedure at most inquiries. Notwithstanding, it will deviate from this procedure to obtain necessary information. A transcript is maintained for most inquiries and evidence is not required to be given under oath. The chairman will give opening remarks introducing the subject matter and the reason for calling the inquiry. Details of Notice are given by Board counsel or Board staff reflecting the distribution of the Notice of Inquiry, and of the Notices to Attend. Registration of participants, if any, who have filed written submissions, or who have been served with a Notice to Attend, will then take place. The order of presentation reflects the order of registration of the participants. The latter matter is within the discretion of the panel and may or may not be known to the participants prior to the inquiry date.

Upon completion of the preliminary matters, the chairman, if a Board staff submission has been prepared, will call upon the Board staff to present its submission. The staff will present its submission, with assistance from Board counsel, and be available for questioning. The staff submission will usually set out background information if the inquiry is investigating an event. If the purpose of the inquiry is to formulate basic data, the staff submission may reflect the results of investigative work completed prior to the inquiry. The Board will then call upon all participants to present their submissions in order of registration.

Both the nature of the inquiry and subject matter being investigated will determine whether the Board will allow cross-examination of submissions by participants. The Board is particularly careful in this regard when investigating events that could result in litigation between participants. The information received from direct evidence is usually more than adequate for the Board's purposes, thus negating any reason for cross-examination. If appropriate and necessary, Board counsel may question the participants. The panel will then question them. Summary statements may or may not be allowed. Upon conclusion of the evidence or summary statements as the case may be, the Board will reserve its observations and recommendations and close the inquiry.

Examiners who have conducted an inquiry will evaluate the evidence and make appropriate observations and recommendations to the Board. The Board will either ratify or alter these recommendations and an inquiry report will be issued. When the Board itself has conducted the inquiry, it will formulate its own observations and recommendations and issue an inquiry report. ${ }^{95}$ When the investigative process has been initiated upon request from the Lieutenant Governor in Council, the report will be directed to him. If the Board has unilaterally called the inquiry, it may direct its report to applicable government departments, agencies within the private sector or utilize its observations for in-house purposes. Copies of the inquiry report are forwarded to all participants.

Recommendations made in an inquiry report can result in legislative changes or changes in practices utilized by industry. The inquiry process

94. Supra n. 80.

95. Supra n. 1, s. 22. 
is valuable in that it may result in beneficial changes both from the public and industrial sector's perspectives.

\section{THE ROLE OF COUNSEL AT BOARD HEARINGS AND INQUIRIES}

\section{A. General Comments}

It has been previously stated in this paper that counsel are beginning to appear with greater frequency before the Energy Resources Conservation Board, and consequently there has been a greater call for procedural formality. On occasion, however, it is the solicitor who fails to comply with the Board's Rules of Practice ${ }^{96}$ and in some cases displays a total lack of knowledge of the Board and its jurisdiction.

There is no doubt that the Board must comply with the requirements of natural justice ${ }^{97}$ when making a decision which may affect the rights of a party to a proceeding. At a minimum, Courts ${ }^{98}$ have imposed upon administrative tribunals a duty to act fairly in proceedings where the tribunal's decision may affect the rights of parties thereto. While the observation of the rules of natural justice by an administrative tribunal may protect the rights of a party to a proceeding, conversely that same recognition of rights may adversely affect the rights of another party to the proceeding. The Board is constantly, through its decision-making process, affecting the private rights of many individuals, and the Board in many instances is placed in a position of having to "weigh the equities".

With the growth of energy development in Alberta and its consequential effects upon the residents of the Province, the public is calling upon counsel to represent them at Board hearings to ensure the preservation of their rights and to protect their interests to the fullest extent. Although the disputes between parties at a Board hearing are not court proceedings, they are nonetheless adversarial. Counsel for interveners are now careful to ensure that an application is put to the full test and that the Board does not approve matters outside its jurisdiction.

Where the public interest is in conflict with private rights, the interest of the public is often elevated in jurisprudence to a superior position. The Board is constantly faced with this consideration. In making decisions, however, a responsible tribunal must attempt, where it can do so reasonably and jurisdictionally, to minimize any adverse effect on the rights of an intervener. There are many situations where it would be difficult for counsel representing an intervener to argue against the approval of an application, but counsel's role may be very instrumental in making the Board fully aware of the particular concerns of the intervener and the ultimate ramifications of the project upon the client.

Concurrent with this increased involvement of solicitors representing interveners, the role of solicitors representing applicants has changed as well. Counsel for applicants are now being required to appear in situations where no counsel may have appeared before and where counsel previously did appear, their role is now changing because of the involvement of solicitors on the other side. Counsel are now being called upon to

96. Supra n. 40.

97. Supra n. 1, s. 29(2).

98. Nicholson v. Haldimand - Norfolk Regional Board of Com missioners of Police (1979) 88 D.L.R. (3d) 671 (S.C.C.) 
respond to jurisdictional and procedural matters which counsel for an intervener may raise and, in turn, are requesting stricter compliance with the Board's Rules. ${ }^{99}$

With the recent increase in involvement of solicitors before the Board, the writers thought it appropriate to comment on the role of counsel in Board proceedings.

B. Counsel for the Applicant

1. Preparing the Application

Generally, applications are prepared by the technical personnel of the applicant, and the solicitor representing the applicant has little input into the preparation of the application. For the most part the format and contents of the application document are usually prepared in accordance with the guidelines that may be set out in the Board's Informational Letters, Interim Directives and Regulations, ${ }^{100}$ relating to the particular approval applied for. Notwithstanding their role in the preparation of the formal application document, solicitors should take care to ensure that the application has been prepared in compliance with relevant legislation and guidelines. Accordingly, the solicitor should review the relevant legislation and previous Board reports to make a determination of the issues facing the Board. With the issues in mind, counsel should then review the application document for clarity, and to ensure that all relevant issues have been dealt with fully and that the requested disposition is clearly set out. Finally counsel must be satisfied that the information and evidence contained in the document would allow the Board to conclude that the application is one which should be approved. It is of particular importance, and this will be emphasized many times, to ensure that the requested disposition is fully set out and is abundantly clear. The applicable sections of the Statutes under which the application is made should be indicated.

\section{Presenting the Application at the Hearing}

a. Introduction of the Application

Counsel should provide the Board with a concise summary of the nature of the application, the sections under which the application is being made, the type of evidence which will be offered in support of the application and an indication to the Board of any critical time factors which the applicant may face. As was previously stated, it is of the utmost importance to indicate to the Board the precise decision which the applicant is seeking.

b. Introduction of the Applicant's Witnesses

Where evidence is adduced through witnesses, and there is more than one technical witness, it is generally the practice in a proceeding before the Board to have the witnesses sit as a panel. In other words, witnesses are not called individually as in a court proceeding, but are questioned collectively, usually with one person acting as spokesman. On occasions where the number of witnesses is very large and the subject matters they will be addressing can be segregated, an applicant may wish to introduce separate panels who will in turn be subjected to direct examination and then cross-examination. It is good practice and it is required by the

99. Supra n. 46.

100. Supra n. 47. 
Rules ${ }^{101}$ to indicate the qualifications of a technical witness when introducing the witness to the Board. This should be done carefully to ensure that the qualifications of the particular witness are emphasized. Often counsel will, after introducing the panel of witnesses, adduce, as an exhibit, the curriculum vitae of the panel and then proceed to make a brief summary of each witness' qualifications. Where a witness has testified in a Board proceeding before, counsel may wish to advise the Board of that fact and then still proceed to introduce the witness' qualifications for the benefit of the participants to the hearing.

\section{c. Errata}

Following the introduction of the witnesses, it is generally an appropriate time to advise the Board of any errata which may be in the application and the supporting materials. As well, the Board should be advised at this time of any revisions to information or data presently before the Board. A better practice would be to have errata material and update material in the hands of the Board and the participants before the opening of the hearing so as to allow all parties sufficient time to review any changes. The correctness of any changes should be confirmed by the spokesman for the witnesses at the time reference is made to the errata and changes.

\section{d. Tendering Exhibits}

It is generally at this stage of the proceedings that the applicant's documents, which are already in the hands of the participants to the proceeding, are entered as exhibits. It is usually advisable to have the spokesman of the witness panel identify the documents, and in the case of the application document and supplementary materials, to indicate that they constitute the applicant's application and were prepared at the direction of the applicant. Additionally, counsel should elicit a statement that the documents constitute the applicant's evidence in the proceeding. Documents which are not then in the hands of the participants to the hearing, and which are for the purpose of establishing facts alleged in the application, should be tendered as exhibits, as they are referred to in the course of the hearing. Once again, counsel should follow the process of identification of the document giving such particulars as title, date and an indication of the evidence it represents.

\section{e. Introduction of Direct Evidence}

Direct evidence is led in two basic ways. First in many of the larger projects the applicant basically relies on the contents of its written application, supplemented by prepared statements read into the record by the spokesman or members of the panel. The statements are generally abbreviated restatements of matters addressed in the application document, and very often are of a "motherhood" nature. This method has certain advantages and may be the preferred method where the application has been properly prepared and where the questions on crossexamination are likely to be simply questions of clarification.

The second method of introducing direct evidence is generally used in situations where the applicant anticipates that there may be a dispute as to facts, or in a case where certain facts must be proved to the satisfaction of the Board as a condition precedent to the Board approving the applica- 
tion. Where the applicant is aware that an intervener will take exception to certain facts which the applicant has alleged in its application, counsel may well be advised to introduce direct evidence through his or her witnesses by a progression of detailed questions, as might be done in a court proceeding. For example, an intervener may in his or her written intervention, indicate that the location of a facility is unacceptable and that the applicant has refused to discuss a mutually acceptable location. The applicant, in entering direct evidence, and in anticipation of the viva voce evidence of the intervener, may very well enter evidence, in sufficient detail through careful direct examination, which would be intended as a rebuttal of anything the intervener might say in presentation of direct evidence.

Counsel for the applicant, after reviewing the filed interventions, should brief the applicant's technical witnesses as to the type of questioning that they may expect on cross-examination. These witnesses should be reminded to maintain their composure and professional manner in situations where they may be confronted by an irate intervener on crossexamination. Of equal importance is for the witness to be co-operative and courteous.

\section{f. Argument}

Counsel should be careful not to introduce evidence at a hearing through argument. Argument should be strictly confined to the facts presented at the hearing and to the position to be taken by the applicant. Once again, counsel should emphasize to the Board the disposition that the applicant is requesting the Board to make. In doing this, counsel should be very cognizant of the Board's jurisdiction and should be sure not to request that the Board do something outside its jurisdiction. Counsel should, where possible, avoid the citation of legal authority because the Board is a technical tribunal of fact and it is not the practice of the Board to interpret questions of law.

\section{Counsel for the Intervener}

\section{Preparing the Intervention}

In representing an intervener, preparing the written intervention is perhaps the most important function of counsel. Prior to preparing the intervention, counsel should be fully versed in the jurisdiction of the Board and its procedure. Additionally, counsel should be fully aware of the nature of the application before the Board and should have reviewed all the issues that are before the Board in the proceeding. The writers cannot overemphasize the importance of counsel in determining what issues the Board will be dealing with and what dispositions the Board can make. All too often, interventions are filed with the Board relating to matters which are either beyond the jurisdiction of the Board or are irrelevant to the considerations of the proceedings before the Board. Irrespective of the client's feelings towards an application, the client should be advised as to the Board's jurisdiction and the written intervention should be drafted accordingly. If counsel files an intervention which deals with issues beyond the jurisdiction of the Board, and if at the hearing the Board must advise counsel for the intervener that it is not prepared to hear evidence in that regard, the client may feel that he is not receiving a fair and reasonable opportunity to present his case. 
In representing an intervener, counsel must recognize that applications may be approved notwithstanding the adverse effects which may be caused to the client by the project. A significant role of counsel is therefore to ensure that the Board is aware of all the effects of the project on the client. Counsel also has a role in ensuring that his or her client has been afforded full procedural fairness and that the decision that results from the proceeding is jurisdictionally correct.

The written intervention should set out the position of the intervener, the reasons for that position, and the facts in support of that position. Counsel must remember that the applicant has certain rights pursuant to the principles of natural justice and, accordingly, the applicant is entitled to know the facts which the intervener proposes to present. The Board often receives interventions which simply state the position of the intervener without any facts in support of that position. This sometimes leaves the applicant in the disadvantaged position of not having had a reasonable opportunity to learn those facts prior to the hearing and accordingly to prepare cross-examination in advance.

Counsel for the intervener should refer to the Rules of Practice when preparing an intervention and should have close regard to time requirements for the purpose of filing documents. All too often, simple procedural requirements are not complied with by solicitors representing interveners.

An important matter which is related to the preparation of the intervention is the briefing of expert witnesses who may be presented at the hearing. In this regard, the role of counsel for the intervener may be more important than the role of the solicitor representing the applicant. Usually the experts presented on behalf of an applicant are in-house personnel and thoroughly familiar with the application. An intervener's expert witness should become extremely familiar with the application and its contents and counsel should carefully brief the witness on Board procedure and the type of cross-examination the witness may expect.

Solicitors representing groups or associations where several members of the group or association will be giving evidence should co-ordinate their clients to ensure a smooth presentation.

2. Presenting the Intervention at the Hearing

a. Introduction of the Intervention

The introduction of the intervention should be carried out in a manner similar to the introduction of the application by counsel for the applicant. That is to say, counsel should give a concise summary of the intervener's position and the reasons for that position. In addition, counsel should state how the intervener wishes the Board to dispose of the applicant's application.

\section{b. Introduction of Witnesses}

Witnesses for the intervener should be introduced in a manner similar to that used by counsel for the applicant. Quite often individual landowners will not have panels of witnesses but will simply give evidence on their own behalf.

\section{c. Tendering of Documents}

The same procedure used by counsel for the applicant when tendering documents should be used. In identifying the document the witness 
should indicate the title of the document, the date of the document and the evidence which the document is intended to represent.

\section{d. Direct Evidence}

The degree of control exercised in the presentation of evidence by counsel for the intervener depends upon the type of witness that the intervener is presenting. While witnesses who give evidence on behalf of an applicant are generally very technical people, the witnesses for the intervener may be lay people. Accordingly, counsel for the intervener may wish to exercise greater control over the introduction of evidence by way of detailed and extensive questioning. Another aspect of counsel's role in appearing before the Board is to inject into the proceedings a sense of composure on behalf of an intervener, thereby confining the intervention to the matters which are before the Board. Often where landowners are not represented by counsel, they feel slighted because they are unfamiliar with the Board's procedure. This, coupled with the concerns that they may have about the application, may result in an intervener presenting a highly excited and emotional case involving matters outside the purview of the hearing and outside the Board's jurisdiction. Counsel should maintain strict control of the introduction of evidence so as to avoid repetition.

One important point to remember is that the direct evidence introduced should be confined to the matters which are set out in the written submission of the intervener. Direct examination should only be an elaboration of those matters and no new information should be introduced at this time.

\section{e. Argument}

The comments previously stated with respect to argument as presented by the applicant apply here also. However, counsel for the intervener should note that he will be required to present his argument first, and accordingly he must remember that he will not ordinarily have a right to reply and should be prepared to raise in his argument all matters which he anticipates the applicant will address. As a practical matter, counsel for the intervener should always be ready to seize an opportunity to be innovative in suggesting possible compromises.

\section{Procedural Matters Relating to Counsel for the Applicant and Counsel for the Intervener}

\section{Redirect and Rebuttal Evidence}

Counsel should keep in mind that redirect should be utilized only to clarify matters which were raised on cross-examination but which counsel feels were not properly addressed at that time. Rebuttal evidence should only be utilized to rebut and to respond to evidence led by an intervener, and should not be used for the purpose of introducing new evidence.

\section{Conduct and Attitude of Counsel}

Although the Board's hearing is relatively formal, the atmosphere is much more relaxed than a Court proceeding. This, however, is no excuse for failure to afford all the parties to the hearing the courtesy to which they are entitled. The Board should be treated in a respectful manner. 


\section{Board's Jurisdiction}

The writers cannot over-emphasize the need for counsel to be aware of the Board's jurisdiction pursuant to its enabling legislation or under the other statutes which it administers. All too often counsel will appear before the Board without being familiar with the scope of the Board's jurisdiction or its procedure. In such cases counsel does not serve the interests of his client and the client may well be better off to present his own case.

\section{Filing Interventions}

It is sometimes the practice of counsel to file an intervention indicating that counsel reserves the right to cross-examine the applicant and to present closing argument. ${ }^{102}$ Two matters arise out of this procedure. First, counsel may by written intervention attempt to reserve the right to introduce evidence at the hearing. This cannot be done because evidence to be introduced at the hearing must be set out in the intervention. ${ }^{103}$ Second, where evidence is not introduced by direct examination, it is sometimes led through the back door during closing argument. Counsel should refrain from this practice because it is an attempt to put evidence before the Board which is not subject to cross-examination.

\section{Tendering Exhibits}

Simply as a matter of courtesy and procedure, counsel, when tendering exhibits before the Board, should have sufficient copies on hand to provide all participants to the hearing with a copy of the document. In many instances counsel will only have one copy of the document to enter as an exhibit and as a result there may be a large number of participants scrambling to examine it.

\section{Undertakings}

When a client has given an undertaking to provide further evidence, his counsel should ensure that all parties to the hearing receive the response to the undertakings. It is good practice to verify, on the record, each undertaking as it is given.

\section{Citing Authority}

As mentioned previously, counsel should refrain from citing legal cases. The Board is a tribunal of fact and when dealing with questions of law, will try to give a literal interpretation, but is reluctant to attempt to apply rules of interpretation. As a quasi-judicial tribunal, the Board is required to assess each application on its own merits. Accordingly, the principle of stare decisis is not applicable. Counsel may wish, however, to refer to previous Board decisions when preparing for an application simply to gain an understanding of how the Board has assessed similar applications and the principles and criteria used by the Board in evaluating an application.

\section{Counsel as a Witness}

On occasion, counsel has appeared at a Board hearing without any witnesses. Counsel has then proceeded to give direct evidence and subject himself to cross-examination. This practice is questionable. Should

102. Supra n. 40, s. 14(1)(e).

103. Supra n. 40, s. 24(1). 
counsel, however, see fit to lead evidence on behalf of his client he must ensure that he is in a position to answer any relevant questions that may arise on cross-examination.

\section{Adjournments}

When counsel for an intervener will be requesting an adjournment prior to the commencement of a hearing, counsel should promptly notify Board counsel and the applicant's solicitor. Following this, a written submission should be filed with the Board and with the applicant, clearly indicating the request and the reasons for it. Generally the Board will review the request and initially ask the applicant if it objects to the adjournment. If the applicant does object, the Board may convene a prehearing meeting with the counsel for the intervener, any other known interveners, counsel for the applicant and Board counsel, to hear arguments on the point. In making these requests, counsel should remember that in many hearings, much planning has gone into setting the matter down for hearing and often a large number of interveners have been given notice of the hearing. Therefore the request should be reasonable and responsible.

\section{Contacting Board Members}

Counsel should refrain from speaking to Board members during the course of the hearing or after the hearing on any matter relating to the application until the decision is made. If counsel wishes to communicate with the Board, he would be best advised to go through the Board solicitor.

\section{The Unrepresented Intervener}

Where an intervener appears at a hearing without counsel, solicitors representing participants should endeavour to accommodate the intervener who may be unfamiliar with the Board's procedure and who may feel out of place in a formal proceeding.

\section{E. Counsel at Board Inquiries}

On the rare occasions where the Board will hold an inquiry, counsel, in assessing what role he will exercise at a proceeding, should determine the nature of the inquiry. Where the inquiry is held pursuant to the request of the Lieutenant Governor in Council, and the Board will be receiving submissions from the public, the procedure for the inquiry will be similar to that for a hearing except that there will be no applicant. Where the inquiry is an investigatory inquiry to determine facts, usually relating to an apparent contravention of the Board's statutes, the procedure may be likened to a court proceeding. In the latter case, the exact procedure may vary from case to case, and counsel would be advised to consult with the Board solicitor.

\section{F. Board Counsel}

Board counsel plays a very limited role during the course of a hearing. The solicitor for the Board generally cross-examines participants to the proceeding on behalf of Board staff. The Board solicitor also has a second role in situations where he is called upon by the Board to render advice to the Board in procedural or jurisdictional matters. The role of Board counsel at Board inquiries which are called for the purpose of receiving submissions is very similar to the role exercised at hearings. That role changes, however, at investigatory inquiries where Board counsel may lead direct evidence through a Board staff submission. 
The Board solicitor will act as a liaison between counsel for the participants and the Board prior to and during the hearing. Any requests relating to procedural matters prior to the opening of the hearing should be directed to the attention of the Board solicitor.

\section{LOCAL INTERVENERS' COSTS}

The Energy Resources Conservation Act and the Local Interveners' Costs Regulations ${ }^{104}$ authorize the Board to make an award of costs to a local intervener who has presented an intervention at a Board proceeding. Since August 1979, the Board has made approximately ninetyfive costs awards and in all cases except one the applicant who initiated the proceeding was ordered to pay the costs.

The Board's jurisdiction to award costs was created in 1978 when the Energy Resources Conservation Act was amended to include s. 30.1. ${ }^{105}$ Specifically, s. 30.1(2) provides:

(2) If a local intervener presents an intervention in a proceeding before it, the Board may award to the local intervener in accordance with the section any costs reasonably incurred by the local intervener in connection with the proceeding.

A local intervener is defined as a person who owns, occupies or is entitled to occupy the land that is or may be directly and adversely affected by a decision of the Board. The definition expressly excludes persons whose business "includes the trading in or transportation or recovery of any energy resource". It is present policy that in order to make an application for an award of costs, a person must participate in a Board hearing by presenting an intervention and that the costs incurred in such a presentation must be reasonable. The Board is given the discretion to determine the amount of costs that may be paid to a local intervener, although s. 6(1) of the Regulation provides: ${ }^{106}$

(1) If the Board awards costs or a portion or share of costs to a local intervener, the portion or share of costs determined by the Board shall not exceed for any matter the costs prescribed in the Schedule.

In spite of this, s. 6(2) of the Regulation provides:

(2) Notwithstanding subsection (1), if the Board in a particular proceeding, having regard to

(a) the need of the local intervener and the parties to the proceeding.

(b) the nature and complexity of the proceeding and intervention, and

(c) the economics of the conduct of the proceeding or intervention,

considers that the amount of costs prescribed in the Schedule would not be appropriate in awarding costs or a portion or share of costs to a local intervener in that proceeding, the Board may vary from the amount of costs prescribed in the Schedule.

This provision clearly authorizes the Board to make a discretionary award in excess of the amounts prescribed in the Schedule.

The Board in determining whether it should award or deny costs is given certain criteria to which it may have regard. To date, the Board has not denied any claim because it was frivolous or vexatious. The Board has denied claims because

(a) the Board did not hold a hearing, or

(b) the local intervener was not in need of legal or technical assistance. The Board has denied portions of claims because of the following:

104. Alta. Reg. $435 / 78$.

105. See R.S.A. 1980, c. E-11, s. 31.

106. Schedule of Costs as attached to Alta. Reg. 435/78. 
(a) the claimant failed to satisfy the Board that the costs were actually incurred,

(b) the claim was excessive, or

(c) the costs incurred did not directly and necessarily relate to the hearing.

The Board has made discretionary awards pursuant to s. 6(2) of the Regulation in the following situations:

(a) where the Board was satisfied that, due to the co-operation of many interveners in presenting a common submission, both time and expense had been saved to all participants,

(b) where the intervention was of particular assistance to the Board in making its decision,

(c) where the proceeding was particularly complex, and in the circumstances, the Schedule would not adequately assist the local intervener with his or her costs, and

(d) where the particular need of the intervener in the circumstances of the proceeding warranted the making of a discretionary award.

Following the conclusion of the hearing, and when the Board is in receipt of the claim for costs, the Board will review the claim to determine if the requirements of $s .3$ of the Regulation (details to be included in the claim) have been met. It is advisable for counsel representing a local intervener who is claiming costs to ensure that the claim will be easily understood and that sufficient detail is included. This allows the Board to determine the type of services rendered, the amount of time involved, the costs of such services and sufficient detail relating to the other portions of the claim. Where a solicitor's account, which usually accompanies a claim, itemizes in detail the services performed, those services should be summarized to allow for easy review of the claim. Of utmost importance is to ensure that any evidence of expenses accompanies the claim.

If the Board finds a deficiency in detail and material, a letter will be sent to the claimant requesting the necessary particulars. As soon as the Board is in receipt of the further particulars the claim and supporting documentation will be forwarded to the applicant for the purpose of obtaining its comments. If comments are received and they appear, in the opinion of the Board, to be prejudicial to the local intervener's claim, the comments are sent to the local intervener with an invitation to reply. Once all is complete, the Board will then review the claim to determine whether it will be allowed or denied, and if allowed, the amount of the claim. The Board will prepare and issue an order along with a letter of reasons, which is forwarded from the solicitor's office. Ordinarily the Board orders the costs to be paid by the applicant, although in a Boardinitiated proceeding, the Board will pay the costs of the local intervener. The local interveners' costs provisions of the Act and Regulation do not have any enforcement provisions whereby an order may be registered with the Court of Queen's Bench or whereby the Board can seek a contempt order on behalf of the local intervener upon failure of the applicant to pay the costs ordered. To the knowledge of the writers no need for such a provision has arisen to date. 
One particular area of the Costs Regulation which has met with question is the provision for appeal. The only reference to an appeal is an appeal from the decision of a taxation officer. This is a procedure set out in ss. 8 and 9 of the Regulation but is totally foreign to the Board. The Board has never appointed a taxation officer and all costs decisions to date have emanated from the Board. In the two instances where the decision of the Board has been appealed, it was recommended to counsel for the local intervener to apply pursuant to s. 42 of the Energy Resources Conservation Act, which provides that:

The Board may review, rescind, change, alter or vary any order or direction made by it, or may hear any application before deciding it.

The Board has jurisdiction to make an advance subject to conditions respecting repayment. Additionally, the Board may direct in a subsequent costs award that the party liable to pay costs to the local intervener reimburse the Board for the amount of the advance.

Requests for an advance of costs should indicate the name of the intervener, the proceeding in which the intervener proposes to participate, a list of expenses which the intervener reasonably expects to incur for the purpose of preparation of the intervention and sufficient details as to why the costs are to be incurred. To date, the Board has only made an advance of costs in relation to disbursements which the Board, in its opinion, reasonably anticipated that the local intervener would incur as a result of his or her preparation of the intervention. Costs have not been advanced in respect of the services of solicitors or consultants. The Board has taken this position because, in making such an advance of costs, it is basically dealing with the monies of the applicant, who may or may not ultimately have to bear the costs of the proceedings. To make an advance with respect to legal fees and expert witness fees would, in effect, be a predisposition as to the merits of the intervention. The Board has, in one Board-initiated proceeding, advanced funds in respect of the fees of the solicitor and the local intervener's consultant because in Board-initiated proceedings it is the Board which bears the interveners' costs.

The Board when making an award of costs adopts a two step procedure. First it reviews the costs claim and tries to apply the Local Interveners' Schedule to the items claimed and the amount claimed. The Board will then calculate the total amount of costs which might be awarded pursuant to the Schedule. If a deficiency results from the amount which may be awarded pursuant to the Schedule and the amounts which have actually been claimed, the Board must determine whether it is prepared in the circumstances of the proceeding to exercise its discretion pursuant to s. 6(2) of the Regulation to make an award in excess of the Schedule.

In preparing a claim for costs, a solicitor representing an intervener should have regard to the Board's method of assessing costs. The solicitor should attempt to set out the claim in a style consistent with the Local Interveners' Costs Schedule. Where the amount which would be allowed pursuant to the Schedule is less than the full costs incurred by the intervener, counsel should request the Board to exercise its discretionary jurisdiction to make an award in excess of the Schedule. When requesting a discretionary award, counsel should be sure to include careful reasons justifying the Board in making such an award. There appears to be a prima facie presumption in the Regulation that the award of costs shall 
not exceed the amount specified in the Schedule, unless the Board is satisfied that the circumstances warrant such a deviation.

Presently the Schedule allows an intervener to claim costs in respect of solicitor fees, witness fees and his or her disbursements. Solicitor's fees may be claimed for both preparation and attendance at the hearing. However, the amount of costs which may be awarded with relation to solicitor's fees is limited to two full days of preparation for a hearing which would result in a total award of $\$ 1,000.00$ for a solicitor's preparation $(\$ 500.00 \times 2)$. The claim for solicitor's attendance at a hearing is not limited and costs may be awarded pursuant to the Schedule at the rate of $\$ 250.00$ per half day or part thereof. Awards made with respect to witnesses are on the basis of $\$ 50.00$ for the witness' attendance upon a solicitor for the purpose of briefing before the hearing and $\$ 25.00$ per half day that the witness is in attendance at the hearing for the purpose of giving evidence. One area of the Schedule which has received the most criticism is the award relating to professional or expert witnesses. At present, the Schedule allows an award of $\$ 150.00$ for the attendance of an expert witness upon a solicitor for the purposes of briefing. The award with respect to fees of an expert witness are limited to $\$ 75.00$ per half day or part thereof that the expert witness attends the hearing. It is quite clear that this amount does not realistically reflect the fees which expert witnesses and consultants are now commanding.

The Schedule, as a whole, has been the subject of criticism. The Schedule is very limiting in two aspects. First, the items for which costs may be awarded often leave the intervener, who did not retain counsel, bearing many of his or her costs. Second, the amounts which may be awarded often leave a significant deficiency of costs.

As a result of this, the Board is presently reviewing the Schedule, although no changes have been made to date.

\section{CONCLUDING REMARKS}

It is apparent from the foregoing that participation of counsel has had a marked influence on the evolution of the procedure presently utilized by the Energy Resources Conservation Board. Inevitably, future participation by counsel before the Board will emphasize the adversarial nature of the process thus necessitating further procedural variations. These variations must result in a practical balance between flexibility and formality so that the process remains fair, orderly and efficient.

It is important that counsel appearing before the Board appreciate their role in the Board's procedural evolution so as not to burden the process with unnecessary technical and jurisdictional arguments. However, it is also imperative for counsel to remind the Board of its responsibility to maintain a procedural framework within which it may discharge its approving and advisory functions. 


\section{APPENDIX A \\ ENERGY RESOURCES CONSERVATION BOARD \\ BANTRY FIELD \\ APPLICATION NO. 810327 \\ N O T I C E}

TAKE NOTICE that, unless objection by a person having a bona fide interest in the matter is filed on or before 25 May 1981 with the undersigned and with the applicant at its address set out below, the Board may grant an application by Aries Resources Limited, pursuant to section 5.100 of the Oil and Gas Conservation Regulations to form the Aries Bantry Gas Block No. 1 and pursuant to section 81, subsection (4), of The Oil and Gas Conservation Act, to suspend the application of Part 4 of the Oil and Gas Conservation Regulations for wells drilled or to be drilled within the block for the production of gas from the Medicine Hat and Milk River Formations.

The Board proposes that if the application is granted the block will be subject to the following conditions:

1. Wells producing within the block from the Medicine Hat and Milk River Formations shall be at least $\mathbf{4 0 0}$ metres from each other well producing from the same formation.

2. A well through which production is taken or will be taken from the said block shall be at least 400 metres from the southern and western boundaries of the block.

3. Production shall be taken from only one well per quarter section completed in the Medicine Hat and Milk River Formations that is contiguous to the northern and eastern boundaries of the gas block.

Copies of the application and information and particulars filed in support thereof may be obtained by interested persons from Aries Resources Limited, (Attention: F. Zagloul), 200 Aries Petroleum Centre, 4393 - 14 Street N.E., Calgary, Alberta, T3E 7 A9.

DATED at Calgary, Alberta on 4 May 1981.

ENERGY RESOURCES CONSERVATION BOARD

Michael J. Bruni, Board Solicitor

640 - 5 Avenue S.W.

Calgary, Alberta

T2P 3G4

\section{APPENDIX B(a) \\ ENERGY RESOURCES CONSERVATION BOARD \\ THE OIL AND GAS CONSERVATION ACT \\ APPLICATION NO. 800908}

\section{NOT I CE OF HEAR I N G}

TAKE NOTICE that the Energy Resources Conservation Board will hold a public hearing at the Convention Inn Hotel, 4404 Calgary Trail, Edmonton, Alberta, on Wednesday, 20 May 1981, at the hour of 9:00 a.m., for the purpose of hearing representations respecting an application by C.I.L. Inc. pursuant to section 42 of The Oil and Gas Conservation Act, for 
an industrial development permit which would authorize the annual use of 110800 tonnes of ethylene as raw material and 7.85 million cubic metres of.gas as fuel in the production of polyethylene at a new plant to be constructed on the site of the applicant's existing polyethylene manufacturing site in the country of Strathcona. The term of the requested permit is 20 years commencing with plant start-up, projected for mid 1984.

Copies of the application and information and particulars filed in support thereof are available for public examination at the offices of the Board, 640 - 5 Avenue S.W., Calgary, Alberta, T2P 3G4 and the Board's Edmonton Office, 12204 - 145 Street, Edmonton, Alberta, T5L 4J5, or may be obtained by interested persons from the applicant, C.I.L. Inc., (Attention: W. G. Pethybridge, Works Manager), P.O. Box 428, Edmonton, Alberta, T5J 2K1.

Any person intending to make a submission with respect to this application shall file, on or before 11 May 1981, fifteen copies of the submission with the undersigned and two copies of the submission with the applicant at its above address.

DATED at Calgary, Alberta on 26 March 1981.

\section{ENERGY RESOURCES CONSERVATION BOARD}

Michael J. Bruni

Board Solicitor

\section{APPENDIX B(b) \\ ENERGY RESOURCES CONSERVATION BOARD \\ COLD LAKE - EDMONTON - LLOYDMINSTER AREA \\ APPLICATIONS NO. 800561, 800562, 800741, $800742,800806,800807$ and 800897 \\ N O T I C E OF HEAR IN G}

TAKE NOTICE that the Energy Resources Conservation Board will hold a public hearing in the Capilano Room of the Capilano Motor Inn, 9125 - 50 Street, Edmonton, Alberta, on Tuesday, 20 January 1981, at the hour of 9:00 a.m., for the purpose of hearing representations respecting applications by Alberta Energy Company Ltd. and Husky Oil Operations Ltd. for permits to construct pipelines and related facilities as shown on the attached map.

APPLICATION NO. 800562:

The applicant, Husky Oil Operations Ltd., proposes to construct 143.10 kilometres of 168.3-millimetre outside diameter pipeline for the transmission of condensate from a refinery in Legal Subdivision 13, Section 1 , Township 50, Range 1, West of the 4th Meridian, to a point in Lsd 4-26-63-4 W4M.

\section{APPLICATION NO. 800561:}

The applicant, Husky Oil Operations Ltd., proposes to construct 131.65 kilometres of $323.9-\mathrm{mm}$ outside diameter pipeline and $10.97 \mathrm{~km}$ of 406.4-mm outside diameter pipeline from the transmission of crude oil and condensate blend from a pump station in Lsd 4-26-63-4 W4M to a refinery in Lsd 13-1-50-W4M. 
APPLICATION NO. 800741:

The applicant, Alberta Energy Company Ltd., proposes to construct $235.01 \mathrm{~km}$ of $168.3-\mathrm{mm}$ outside diameter pipeline and $6.75 \mathrm{~km}$ of $114.3-\mathrm{mm}$ outside diameter pipeline for the transmission of sour condensate from a pump station in Lsd 6-5-53-23 W4M to a point in Lsd 13-5-65-3 W4M.

APPLICATION NO. 800742:

The applicant, Alberta Energy Company Ltd., proposes to construct $235.09 \mathrm{~km}$ of $323.8-\mathrm{mm}$ outside diameter pipeline and $6.75 \mathrm{~km}$ of $219.1-\mathrm{mm}$ diameter pipeline for the transmission of sour crude oil and condensate blend from a pump station in Lsd 13-5-65-3 W4M to a point in Lsd 2-5-53-23 W4M.

APPLICATION NO. 800806:

The applicant, Alberta Energy Company Ltd., proposes to construct a 400 kilowatt pump station and measurement facilities in Lsd 6-5-53-23 W4M.

APPLICATION NO. 800807:

The applicant, Alberta Energy Company Ltd., proposes to construct $1240 \mathrm{~kW}$ pump station and measurement facilities in Lsd 13-5-65-3 W4M. APPLICATION NO. 800897:

The applicant, Husky Oil Operations Ltd., proposes to construct an oil battery, truck terminal and crude oil blending facilities in Lsd 4-26-63-4 W4M.

Copies of the applications and information and particulars filed in support thereof may be obtained by interested persons from Husky Oil Operations Ltd.'s agent:

Applications No. 800561, 800562 and 800897

or from Alberta Energy Company Ltd.:

Applications No. 800741,

800742,800806 and 800807

Algas Engineering Services Ltd. P.O. Box 2535, 205 - 5 Avenue S.W. Calgary, Alberta, T2P 2N6 Attention: W. C. Thompson

Alberta Energy Company Ltd. 1200, 10707 - 100 Avenue

Edmonton, Alberta, T5J 3M1

Attention: J. H. Russell

Any person intending to make a submission with respect to any of these applications shall file, on or before 7 January 1981, ten copies of the submission with the Board at its address set out below, and two copies with each of the applicants at their above addresses.

AND FURTHER TAKE NOTICE that submission relating exclusively to matters of compensation are beyond the jurisdiction of the Energy Resources Conservation Board.

DATED at Calgary, Alberta on 3 December 1980.

ENERGY RESOURCES CONSERVATION BOARD

Michael J. Bruni, Board Solicitor

640 - 5 Avenue S.W.

Calgary, Alberta

T2P 3G4 


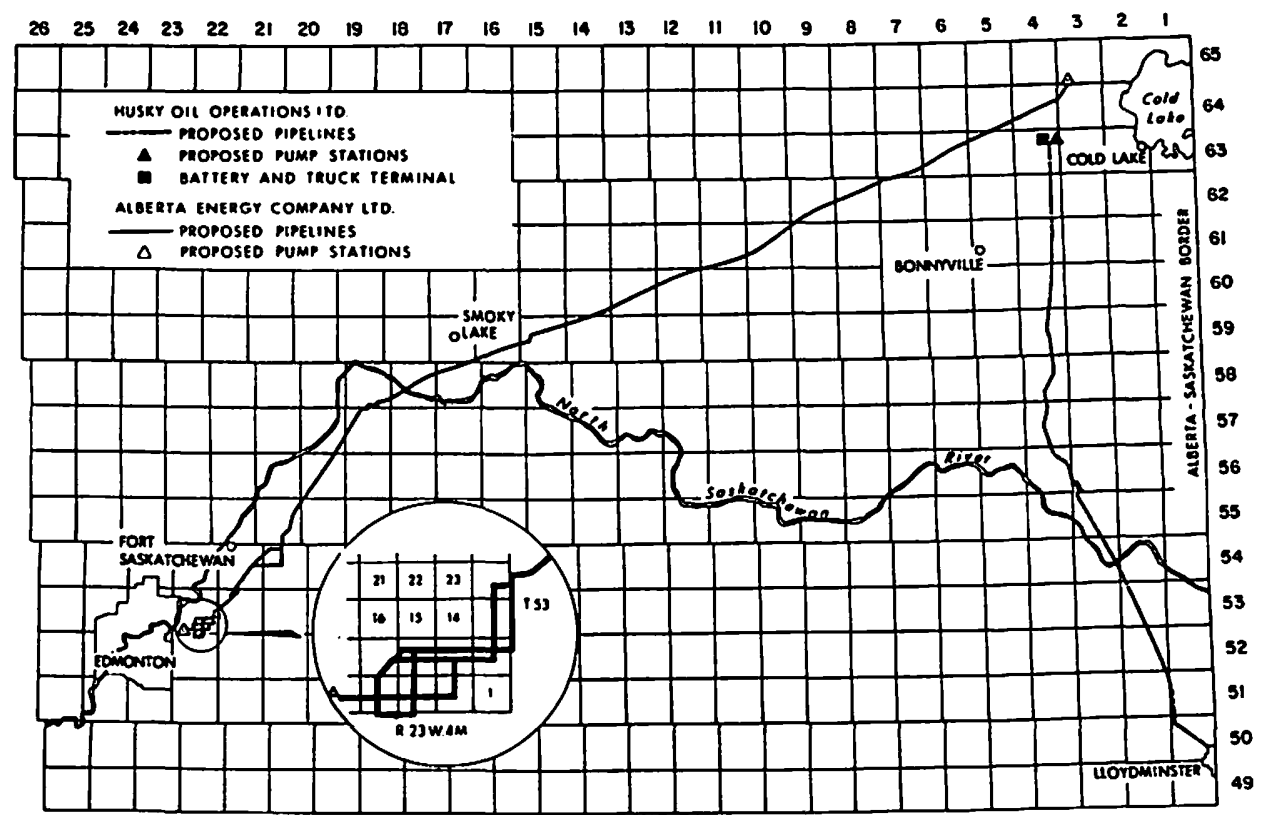

PROPOSED PIPELINES - COLD LAKE EDMONTON - LLOYDMINSTER

\section{APPENDIX B(c) \\ ENERGY RESOURCES CONSERVATION BOARD \\ DICKSON RESERVOIR \\ $240 \mathrm{kV}$ TRANSMISSION LINE RELOCATION \\ APPLICATION NO. 800886}

NOT I CE OF HEAR IN G

TAKE NOTICE that examiners appointed by the Energy Resources Conservation Board will hold a public hearing at the Red Deer Provincial Provincial Court House, 4836 Ross Street, on Wednesday, 17 June 1981, at the hour of 9:00 a.m., for the purpose of hearing representations respecting an application by Calgary Power Ltd. for a permit to relocate and a licence to operate three $240 \mathrm{kV}$ transmission lines in the Dickson Dam area.

The possible alignments of the electric transmission lines proposed to be relocated are indicated on the attached map. Any combination of the various alignments may be considered for the route. Variations within one-half mile of the alignments shown may be approved.

Copies of the application and information and particulars filed in support thereof may be obtained by interested persons from the applicant, Calgary Power Ltd., (Attention: Mr. E. L. Murgatroyd), P.0. Box 1900, 110 - 12 Avenue S.W., Calgary, Alberta, T2P $2 \mathrm{M} 1$.

Any person intending to make a submission with respect to the application shall file, on or before $8 \mathrm{June} 1981$, ten copies of the submission with the Board at its address set out below and two copies of the submission with the applicant at its above address. 


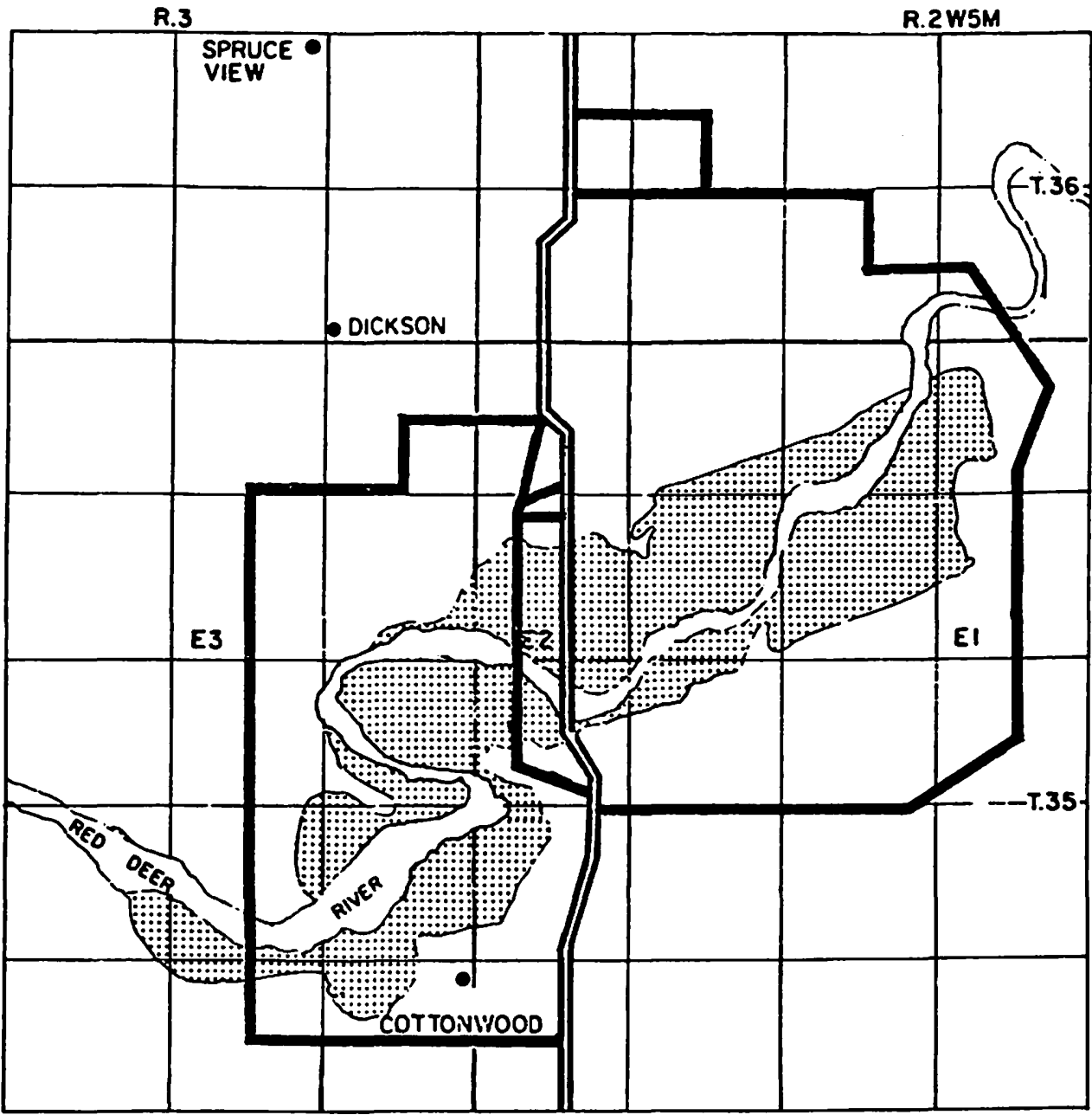

DICKSON DAM AREA

Applicotion No. 800886

EXISTING CALGARY POWER LTO

$240 \mathrm{kV}$ TRANSMISSION LINE

PROPOSED RESERVOIR

POSSIBLE ALIGNMENTS OF THE

CALGARY POWER LTD. $240 \mathrm{kV}$

TRANSMISSION LINES PROPOSED

TO BE RELOCATED.

AND FURTHER TAKE NOTICE that submissions relating exclusively to matters of compensation are beyond the jurisdiction of the Energy Resources Conservation Board.

DATED at Calgary, Alberta on 24 April 1981.

ENERGY RESOURCES CONSERVATION BOARD

Michael J. Bruni, Board Solicitor

640 - 5 Avenue S.W.

Calgary, Alberta

T2P 3G4 


\section{APPENDIX C \\ ENERGY RESOURCES CONSERVATION BOARD \\ ALBERTA - BRITISH COLUMBIA 500 kV INTERCONNECTION POINT PROCEEDING NO. 810326}

\section{NOT I C E OF INQUIRY}

WHEREAS by an application registered with the Energy Resources Conservation Board on December 12, 1978, and numbered 780709, Calgary Power Ltd. applied for permission to build and operate a $500 \mathrm{kV}$ substation and transmission line in southern Alberta; and

WHEREAS the Board held a public hearing in several sessions during 1979 to consider the application; and

WHEREAS the Board prepared and issued its decision with respect to Application No. 780709 as Report 80-D, dated 26 June 1980 and entitled " $500 \mathrm{kV}$ Transmission Line - Langdon - Phillipps Pass"; and

WHEREAS the Board issued Permit and Licence No. CP 80-45, dated 16 April 1981, for a portion of CP 1201L, from Langdon substation to D33, and Permit and Licence No. CP 80-46, dated 16 April 1981, for Langdon substation 102S, as indicated on the attached map; and

WHEREAS by Order In Council 322/81, dated 25 March 1981, the Lieutenant Governor in Council requested the Energy Resources Conservation Board to make inquiries into and report on

(a) alternative locations in the general area of southwestern Alberta interconnection with the facilities of the British Columbia Hydro and Power Authority, and

(b) the most suitable point of interconnection having regard for all relevant considerations.

THEREFORE TAKE NOTICE tha the Board invites submissions addressing

(a) alternative locations in the general area of southwestern Alberta for interconnection with the facilities of the British Columbia Hydro and Power Authority,

(b) alternative transmission line routes between the alternative interconnection location and D33 of transmission line CP 1201L found on the attached map, and

(c) the most suitable point of interconnection having regard for all relevant considerations.

Any person or group of persons intending to make a submission with respect to this matter shall file, on or before 17 August 1981, twenty copies of the written submission with the Board at its address set out below.

AND FURTHER TAKE NOTICE that providing the submissions filed demonstrate a need for further consideration, the Energy Resources Conservation Board will hold a public inquiry at 9:00 a.m., on Tuesday, 27 October 1981, at the Elks Community Hall No. 15, 20 Avenue and 29 Street, Blairmore, Alberta, to consider the submissions filed with the Board.

In order to discuss matters respecting the preparation of submissions, a meeting will be convened and attended by Board staff at 7:00 p.m., on 
ENERGY RESOURCES CONSERVATION BOARD INQUIRY ALBERTA -BRITISH COLUMBIA $500 \mathrm{kV}$ INTERCONNECTION POINT

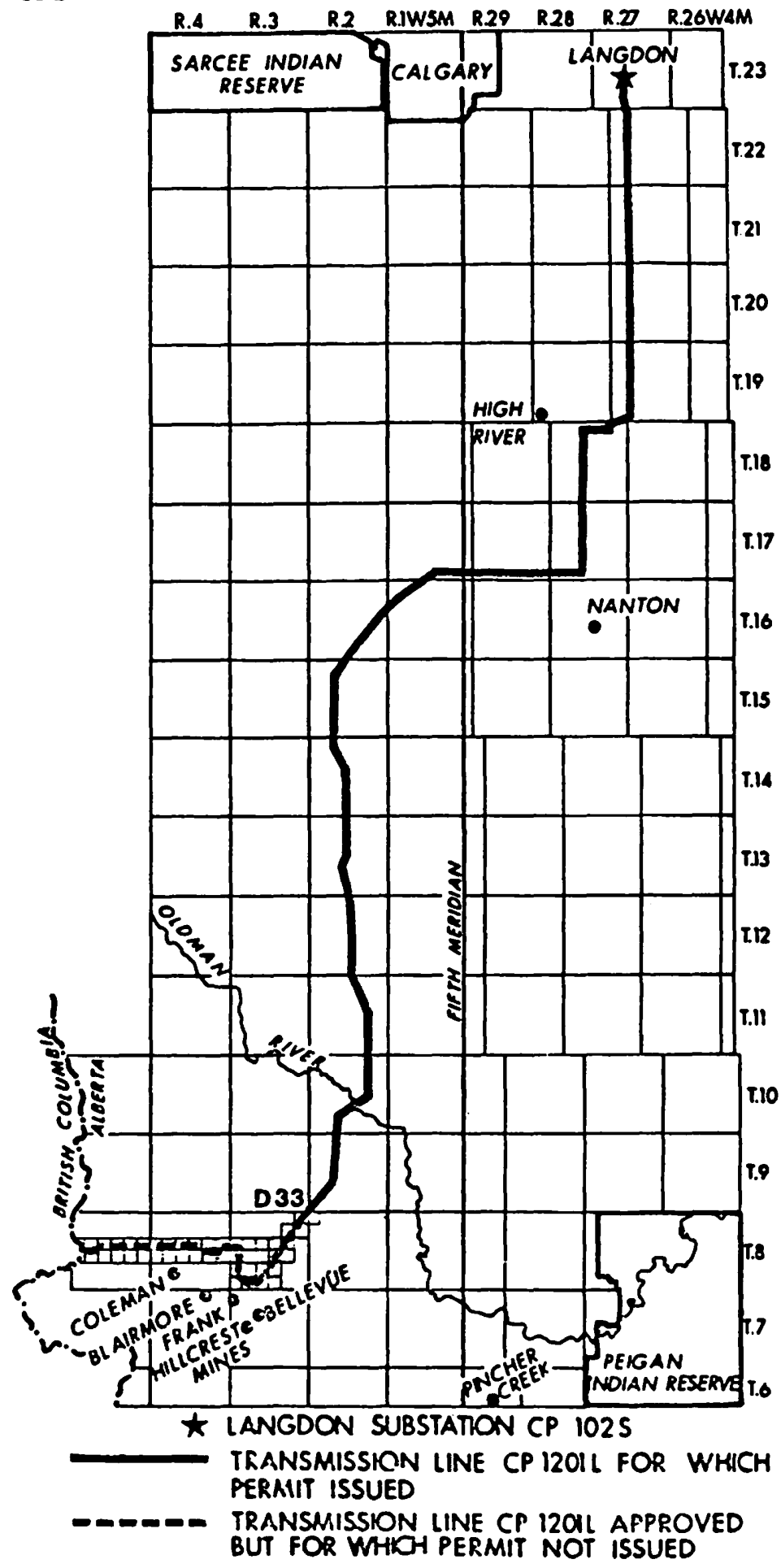


Monday, 11 May 1981, at the Elks Community Hall No. 15, 20 Avenue and 29 Street, Blairmore, Alberta.

DATED at Calgary, Alberta on 28 April 1981.

ENERGY RESOURCES CONSERVATION BOARD

Michael J. Bruni, Board Solicitor

640 - 5 Avenue S.W.

Calgary, Alberta

T2P 3G4

\section{APPENDIX D(a) \\ ENERGY RESOURCES CONSERVATION BOARD \\ PROCEEDING NO.}

NOTICE TO ATTEND AND PRODUCE

TO:

TAKE NOTICE that you will be required to produce an officer of the company, knowledgeable of the relevant facts relating to this inquiry, to give evidence touching the matters in issue in the within inquiry; and

TAKE NOTICE that you are required to produce on the within inquiry all books, papers and documents which you may have in your custody, possession or power, touching the matters in issue in the within inquiry. day of

DATED at the City of Calgary, in the Province of Alberta, this

ENERGY RESOURCES CONSERVATION BOARD

Michael J. Bruni, Board Solicitor

640 - 5 Avenue S.W.

Calgary, Alberta

T2P $3 \mathrm{G} 4$

\section{APPENDIX D(b) \\ ENERGY RESOURCES CONSERVATION BOARD \\ PROCEEDING NO.}

\section{NOT I CE TO A P P A R}

TAKE NOTICE that the Energy Resources Conservation Board has directed that an inquiry be convened at Calgary, in the Province of Alberta, on the day of to inquire into the facts relating to the

and that attached hereto is a copy of the Notice of Inquiry, dated

AND FURTHER TAKE NOTICE that the Energy Resources Conservation Board has reason to believe that you may have knowledge of the relevant facts relating to this matter. 
THEREFORE TAKE NOTICE that you will be required to appear at the aforementioned inquiry on

to give evidence touching the matters in issue in the within inquiry.

DATED at Calgary, Alberta on

ENERGY RESOURCES CONSERVATION BOARD

Michael J. Bruni, Board Solicitor

640 - 5 Avenue S.W.

Calgary, Alberta

T2P $3 G 4$

\section{APPENDIX E \\ * SCHEDULE OF MATTERS REQUIRING BOARD APPROVAL}

\begin{tabular}{|c|c|c|c|}
\hline Functions & Statute & Section & Form of Approval \\
\hline $\begin{array}{l}\text { 1. Approval to Drill a } \\
\text { Well }\end{array}$ & $\begin{array}{l}\text { Oil and Gas } \\
\text { Conservation Act }\end{array}$ & 24 & Well Licence \\
\hline 2. Designation of Fields & $"$ & $21(1)(a)$ & F Order \\
\hline 3. Designation of Pools & $"$ & $21(1)(b)$ & G Order \\
\hline $\begin{array}{l}\text { 4. Designation of Oil } \\
\text { Sands Deposit }\end{array}$ & $"$ & $21(1)(c)$ & OSD Order \\
\hline 5. Designation of Zones & $"$ & $21(1)(e)$ & Zone Designation \\
\hline 6. Prorationing of Oil & $"$ & 22 & MD Order \\
\hline $\begin{array}{l}\text { 7. Setting Rateable Take } \\
\text { of Gas }\end{array}$ & $"$ & 23 & Misc Order \\
\hline $\begin{array}{l}\text { 8. Approval of Enhanced } \\
\text { Recovery Schemes }\end{array}$ & $"$ & $26(1)(a)$ & Approval \\
\hline $\begin{array}{l}\text { 9. Approval of Gas } \\
\text { Processing Plants }\end{array}$ & $"$ & $26(1)(b)$ & Approval \\
\hline $\begin{array}{l}\text { 10. Approval of Underground } \\
\text { Storage of Gas }\end{array}$ & $"$ & $26(1)(b)$ & Approval \\
\hline $\begin{array}{l}\text { 11. Approval of Water } \\
\text { Disposal }\end{array}$ & $"$ & $26(1)(c)$ & Approval \\
\hline $\begin{array}{l}\text { 12. Approval of Production } \\
\text { of Gas in Association } \\
\text { with Oil (concurrent } \\
\text { production) }\end{array}$ & $"$ & $\begin{array}{l}26(1)(e) \\
29(1)\end{array}$ & Approval \\
\hline $\begin{array}{l}\text { 13. Approval of Production } \\
\text { of Gas in Association } \\
\text { with Oil Sands (concurrent } \\
\text { production) }\end{array}$ & $"$ & $\begin{array}{l}26(1)(f) \\
29(2)\end{array}$ & GB Order \\
\hline $\begin{array}{l}\text { 14. Approval of the Use of } \\
\text { an Energy Resource as a } \\
\text { Raw Material or Fuel } \\
\text { in an Industrial or } \\
\text { manufacturing Operation }\end{array}$ & $"$ & 30 & $\begin{array}{l}\text { Industrial } \\
\text { Development } \\
\text { Permit }\end{array}$ \\
\hline $\begin{array}{l}\text { 15. Approval of Oil Sands } \\
\text { Schemes }\end{array}$ & $"$ & 31 & Approval \\
\hline
\end{tabular}




\section{Functions}

16. Declaring a Common Carrier

17. Declaring a Common Purchaser of Gas

18. Declaring a Common Purchaser of Oil

19. Declaring a Common Processor

20. Ordering Compulsory Pooling

21. Approval to Commingle Production

22. Prescribing Special Drilling Spacing Units

23. Establishing Multiple DSU Production Spacing Units

24. Establishing Blocks

25. Approval to Construct Hydro Developments

26. Approval to Operate Hydro Developments

27. Approval to Construct or Operate a Power Plant

28. Approval to Construct a Transmission Line

29. Approval to Operate a Transmission Line

30. Direction to Interconnect with other Facilities

31. Approval to Construct and Operate Electric Distribution System

32. Approval to Construct a Pipeline

33. Approval to Operate a Pipeline

34. Approval of Deep Hole Drilling

35. Approval to Develop a Mine Site or a Mine

36. Approval of Mining Operations
Oil and Gas

Conservation

Regulations

$\begin{array}{ll}" & 40 \\ " & 39 \\ " & 42 \\ " & 72 \\ " & 3.05 \\ & \end{array}$

Hydro and 7

Electric Energy Act

$"$

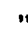

12

14

17

23

7

Act, 1975

Coal

Conservation Act

40

39

42

Misc Order

Misc Order

Misc Order

Misc Order

72 \& $73 \quad$ P Order

$3.050 \quad$ MU Order

4.030 SU Order

5.020 PSU Approval

Block Approval

Permit

Licence

Approval

Permit

Licence

Misc HE Order

Approval

Permit

Licence

10(1)(a) Permit

10(1)(b) Permit

11

Licence 


\begin{tabular}{|c|c|c|c|}
\hline Functions & Statute & Section & Form of Approval \\
\hline $\begin{array}{l}\text { 37. Permit Suspension } \\
\text { or Abondonment of } \\
\text { a Mine }\end{array}$ & $\begin{array}{l}\text { Coal } \\
\text { Conservation Act }\end{array}$ & 16 & $\begin{array}{l}\text { Abandonment } \\
\text { Approval }\end{array}$ \\
\hline $\begin{array}{l}\text { 38. Approval to Construct } \\
\text { or Operate a Coal } \\
\text { Processing Plant }\end{array}$ & $"$ & 23 & Approval \\
\hline $\begin{array}{l}\text { 39. Approval to Suspend } \\
\text { or Abandon Operations } \\
\text { of a Coal Processing } \\
\text { Plant }\end{array}$ & $"$ & 27 & $\begin{array}{l}\text { Abandonment } \\
\text { Approval }\end{array}$ \\
\hline $\begin{array}{l}\text { 40. Approval to Use Coal } \\
\text { as a Raw Material, } \\
\text { Reductant or } \\
\text { Fuel in any Industrial } \\
\text { or Manufacturing } \\
\text { Operation }\end{array}$ & $"$ & 28 & $\begin{array}{l}\text { Industrial } \\
\text { Development } \\
\text { Permit }\end{array}$ \\
\hline $\begin{array}{l}\text { 41. Name and Limits } \\
\text { of a Coal Field }\end{array}$ & $\begin{array}{l}\text { Coal Conservation } \\
\text { Regulations }\end{array}$ & $80(1)$ & CF Order \\
\hline $\begin{array}{l}\text { 42. Permit the Removal } \\
\text { of Gas }\end{array}$ & $\begin{array}{l}\text { Gas Resources } \\
\text { Preservation Act }\end{array}$ & 4 & $\begin{array}{l}\text { Permit (gas } \\
\text { removal) }\end{array}$ \\
\hline $\begin{array}{l}\text { 43. Order Tract } \\
\text { Unit Operation }\end{array}$ & $\begin{array}{l}\text { Turner Valley } \\
\text { Unit Operations Act }\end{array}$ & 3 & TVU Order \\
\hline $\begin{array}{l}\text { 44. Award of Costs to } \\
\text { Local Interveners }\end{array}$ & $\begin{array}{l}\text { Energy } \\
\text { Resources } \\
\text { Conservation Act }\end{array}$ & 31 & Costs Order \\
\hline
\end{tabular}

